\title{
Vitalist temptations: Life, earth and the nature of war
}

\author{
Ian Klinke (University of Oxford)
}

This article stages an encounter between contemporary vitalist thought and the work of the controversial zoologist turned political geographer Friedrich Ratzel (1844-1904). The remarkable degree of congruence between Ratzel's ideas and contemporary more-than-human geography, I argue, opens up crucial questions about vitalism as a political project. A discussion of Ratzel's concept and personal experience of war brings into sharp focus a number of problems in the academic language used by vitalism to blur the boundary between nature and society. The article concludes by suggesting that vitalism should pay closer attention to its own place in the history of modern biopolitical thought.

\section{Introduction}

Human geography has been haunted by a spectre, the spectre of vitalism. Exploring processes at the boundary of nature and society, vitalist thought has sought to draw attention to the dynamic and inventive nature of life itself. As part of a larger turn to materialist and more-thanhuman geographies, vitalism (sometimes neo-vitalism) seeks to understand the intimate connections between the geo (earth) and bio (life), the ways in which the two are intertwined and 'molten' (Whatmore, 2006). Vitalism tries to grasp the world not by reference to a fixed set of human agencies, but rather by examining the vibrancy and disruptive activity of a whole range of organic and inorganic forces. Much like actor-network-theory, it argues that this type of research must necessarily bridge the natural and social sciences, physical and human geography.

This new human and non-human geography is often underwritten by an affirmative mode of critique that seeks to encounter the world through a politics of curiosity and wonder rather than explaining it, in the register of disenchantment, by reference to pre-given power structures. Vitalism is thus part of a broader materialist turn that sees itself as an analytical and political alternative to $19^{\text {th }}$ century environmental determinism as well as late $20^{\text {th }}$ century Marxist geography and social constructivism. Though not a fully-fledged school of thought or 
theoretical paradigm, vitalism is what I would call a temptation in contemporary geographical research and writing, which can often be found in close proximity to the broader 'more-thanhuman' label.

As if to affirm their own language and practice, vitalist concepts and ideas have already left their mark on the Anglophone geographical discipline over the past decade or two (Braun, 2008; Greenhough, 2010; Philo, 2007; Ruddick, 2017; Whatmore, 2005; 2006). Already in 2008, Braun noted that vitalism was 'all the rage' (Braun, 2008: 675) and more recently, Harrison (2015: 285) has added that 'theories of life, of vitality, and of affirmation' have remained 'in the ascendant', with Gandy and Jasper (2018: 143) even speaking of a 'vitalist turn'. In a recent editorial, Philo (2017: 257) notes the 'pervasive tone' to these new geographies - ' $[\mathrm{t}]$ hey are and feel rich, lively, indeed vital; they seem to promise so much more excitement, energy'.

Over recent years, vitalism has steadily grown from its base in cultural and environmental geography to cautiously infiltrate discussions in political geography, too (Dittmer, 2014: 388; 2017; Elden, 2017; Shaw, 2012: 615; Squire, 2015: 147). Whilst attempts to flesh out a more-than-human geopolitics tend to zoom in on the interaction of humans and technology in and around the battlefield, there is now a growing body of work that has begun to explore the hybrid natures of war, sometimes with reference to vitalist theory (Forsyth, 2016; 2017; Gregory, 2016: 5; Johnson, 2015: 304). Here, war emerges in the encounter of vibrant materials, non-human agencies and human subjectivity.

And yet, vitalism has not been without its critics. Cresswell points out that the vitalist emphasis on the insatiable creativity of life may work well to explain social change, but struggles, without any recourse to social structure, to understand why things often stay the same (Cresswell, 2012: 103). Philo laments the relative absence of a focus on epistemic and structural violence within the project of a more-than-human geography (Philo, 2017), whilst Harrison (2015) complains that life is only discussed in affirmatively and celebratory ways, rather than by paying service to loss, vulnerability and finitude. There are political problems, too. Castree (2011) criticises Bennett (2010a), an influential vitalist theorist, for her unwillingness 'to spell-out' why a new vitalist politics is indispensable and how it is to be achieved. Others too have noted that the shift from ontology to politics/ethics is not a smooth one in vitalism/more-than-human geography (Braun, 2011; Ginn, 2014), a point further developed by Lemke, who criticizes a 'systematic blindness concerning the inequalities, asymmetries and hierarchies enacted in vital materialisations' (Lemke, 2018: 3). Intriguingly, Abrahamsson has spotted in the new vital materialism a reluctance to confront the more problematic figures that inhabit its own history. He points to 'lacunae relating to the ethical and political consequences that come with 
translating vitalist thought into political thought' (Abrahamsson, 2013: 38). One of the geographers who Abrahamsson urges contemporary vitalists to re-examine is the German Friedrich Ratzel.

Friedrich Ratzel (1844-1904) is commonly acknowledged today as the founding father of political geography. ${ }^{1} \mathrm{He}$ is also known for having popularized, if perhaps not coined, the controversial term Lebensraum (living space). As is widely known, Ratzel's ideas were posthumously spread by the political scientist Rudolf Kjellén and the geographers Ellen Semple and Karl Haushofer, eventually finding their way into National-Socialist ideology through Haushofer geopolitical advocacy (Smith, 1980; Ó Tuathail, 1996). As a consequence, the vast majority of Anglophone work has approached Ratzel as an early thinker of geopolitics whose dynamic understanding of space appealed to the imperial mind (Dodds and Atkinson, 2000). And yet, Ratzel was also a bio-geographer. Indeed, the trained zoologist is sometimes credited with having coined the term 'biogeography' itself (Müller, 1996; though see Barua, 2018). Towards the end of his life, Ratzel returned to biogeography as he sought to develop a monist theory of all life, in which the human was something of an effect of the natural world. It was at this time that he articulated most clearly an understanding of life as a form of becoming, a creative force that was intimately intertwined with the earth's materiality. Like that of contemporary vitalists, Ratzel's more-than-human geographies rested on the assumption that geography should operate at the interface of science and humanities - even art. He too offered an analytical disposition of wonder and enchantment, as we will see below.

Ratzel may not have identified as a vitalist. And yet, the resemblance between Ratzel's work and contemporary vitalism has not gone unnoticed (Barua, 2018). Verne notes the shared philosophical roots of contemporary more-than-human geography and Ratzel's work (Verne, 2017: 90; see also discussion in Keighren, 2018). If Ratzel stealthily features in contemporary debates, she asks, then have we 'been too radical in condemning his work only as poison?' (87). Others have long been skeptical about the promise that Ratzel's ideas might hold for contemporary social theorists, pointing both to his soil mysticism and to a lack of conceptual precision, both of which were already noted by his contemporaries (Schultz, 2007; 2014). And yet, the question of whether there is more to Ratzel than meets the eye is worth exploring, not least because Ratzel's work is more varied and complex than often recognised and because the question of life (his vitalism) has been thus far subordinated in an assessment of Ratzel to that of the earth (his geo-determinism). The answer, I would like to suggest, is not only a difficult

\footnotetext{
${ }^{1}$ Note that Ratzel has also been read as the last heir to the Erdkunde tradition. Initiated by Alexander von Humboldt and Carl Ritter, this tradition of geographical thought saw itself as a bourgeois answer to a more instrumental, cartographic and ultimately feudal geography, which had dominated $18^{\text {th }}$ Prussia (Farinelli, 20oo).
} 
and highly political one - but one worth struggling with in the light of recent debates about 'life' across the social sciences and humanities. There are problems in contemporary vitalism, I argue, which come into focus when viewed through the lens of that perhaps most destructive of sociopolitical institutions - war.

Let us briefly return to Abrahamsson's insistence that the new vitalists have missed an opportunity to think through the consequences of converting vitalist into political thought. Indeed, the question is whether vitalism is inherently political or whether it is open to a number of political logics. For if vitalism is receptive to both a late $19^{\text {th }}$ century imperial politics as much as an early $21^{\text {st }}$ century ecological cosmopolitanism, then vitalism either lacks a distinct sense of the political, or is sufficiently capacious that it can accommodate a number of very different political projects and positions. Bennett hints at this possibility in her response to Abrahamsson's critique of her book Vibrant matter (Abrahamsson, 2011), even if she insists that it is important 'to break the sense of necessity that exclusive humanists have forged between vitalism and violence' and to give a priority 'to the voice of wonder' (Bennett, 2011: 406). Bennett's brand of vitalist materialism, she explains, is a step away from an agonist understanding of politics, which sees the latter 'as the formation of and struggle over differentials in power, where power is seen as most often taking the form of a zero-sum game' (ibid; see also Bregazzi and Jackson, 2016).

In what follows, I plunge the new vitalists and their sceptics into Ratzel's vibrant world in order to re-examine the claims and counter-claims associated with this intellectual history. In the section that follows, contemporary vitalist geography and philosophy are reviewed and critiqued. Secondly, I survey Ratzel's later work to argue that the conceptual congruence between the new vitalism and Ratzel runs considerably deeper than has been recognised so far. Thirdly, I zoom in on the phenomenon of war as a litmus test for the politics of a vitalist theory. By interrogating Ratzel's concept of war and his formative experiences of the 1870/71 FrancoPrussian war, I suggest that there is little in vitalism to protect it from an aestheticisation of war as a spectacle of natural forces, an outburst of the creativity of life itself. The article concludes by proposing that vitalism should be read as a crucial episode in the history of modern biopolitical thought, and emphasises Ratzel's crucial contribution therein.

\section{Vitalist geographies}

Whilst contemporary vitalist geographers often draw inspiration in some way or another from the $20^{\text {th }}$ century philosopher Gilles Deleuze, vitalism in fact originated in debates among $18^{\text {th }}$ 
and $19^{\text {th }}$ century biologists. In these early debates, vitalists asserted that life could not be collapsed into the laws of chemistry and physics; there inhered in it a unique and untameable energy. Whilst vitalism thus originally emerged in resistance to (mechanistic) materialism, it is today often cast as part of a larger materialist agenda (Coole and Frost, 2010: 9). It is not my intention here to provide a full account of all vitalist arguments that have infiltrated both geography and philosophy (for a useful summary see Greenhough, 2010; see Protevi, 2012 on Deleuze's vitalism). Rather, I establish a broad working definition of vitalism that will enable me to map out the overlap with Friedrich Ratzel's theoretical universe. In doing so, I will explore four arguments that lie at the heart of the vitalist project: (1) an attempt to bring into focus the creative force of life, (2) an effort to reveal the impossibility of separating life and earth, organic and inorganic matter, (3) a move beyond the anthropocentrism of geographical inquiry, and (4) a turn to experiential modes of gathering knowledge with an eye to a politics of enchantment regarding human and non-human life. ${ }^{2}$

Firstly, and most importantly, vitalism remains committed to 'the idea of the specificity and irreducibility of life' (Osborne, 2016: 189). Emerging from this is an understanding of life as continuous process and omnidirectional movement, it is becoming rather than being (Fraser, Kember and Lury, 2005: 3-4). 'There is finality because life does not operate without directions; but there is no "goal"', Deleuze writes (1988: 106). Henri Bergson speaks of an élan vital to capture this exceptional quality, indeterminacy, excess or spirit that causes things to happen in the world. In life adheres thus a creativity that subjects the world to constant evolution and innovation and which is difficult if not impossible to contain and discipline. As Bergson famously puts it, '[i]n vain we force the living into this or that one of our moulds. All the moulds crack. They are too narrow, above all too rigid, for what we try to put into them' (Bergson, $1911[1983]: x)$.

Secondly, vitalism proposes a different sense of what matters. By refusing 'to separate out material processes from the way in which they are encountered as part of the lived experiences of human and non-human actors' (Greenhough, 2010: 41), vitalist geography seeks to understand life and earth as intimately intertwined. Matter and life are thus in a radical openness to one another. 'In the life sciences as well as in physics', Coole and Frost (2010: 15) note, 'material phenomena are increasingly being conceptualised not as discrete entities or closed systems but rather as open, complex systems with porous boundaries'. By extending this understanding of the inextricability of organic and inorganic matter and by treating the latter

\footnotetext{
${ }^{2}$ This is not to say that all vitalisms adhere to this definition or that these individual elements cannot also be found in neighbouring theoretical approaches.
} 
as lively, vitalist materialism also questions any sharply drawn boundary between life and death (Povinelli, 2016: 46). As Lash explains, in 'vitalism life is not at all counterposed to death. Instead death is part of life. Our future is always inorganic matter. Death is seen as entropic, and part of the recombinant life process' (Lash, 2006: 326 ).

Thirdly, vitalist geography has rejected anthropocentrism and embraced a broadly posthumanist agenda. This has entailed both the dethroning of the human subject as a distinctive biological or moral entity and a flattening of relations between humans and non-humans, organic and inorganic agencies (Coole and Frost, 2010: 17). As a consequence, vitalists often celebrate a tendency to anthropomorphise the non-human world in an attempt to question the latter's uniqueness (Bennett, 2010a: 98). This endorsement of a broadly biocentric worldview has entailed an analytical move away from the things that mark humans and their societies out as extraordinary, particularly the capacity for representation and textuality. Instead of examining the world as one of meaning that humans cannot escape, new materialists urge us to engage with that which lies beyond the symbol. By displacing the human subject at the heart of intellectual inquiry, important questions are raised about the way in which the relations between the human and the non-human as well as between life and non-life should be understood and governed ethically.

Fourthly, vitalists (in the Bergsonian tradition at least) emphasise perception, sensation and experience both as ways of being that matter out there in the world that geographers seek to understand and in here, in the encounter of the researcher with the researched. Vitalist geographies thus seek to move beyond the ocularcentrism of the geographical gaze and seek to produce knowledge on that which can be sensed rather than merely seen. In an attempt to think science and metaphysics together (Deleuze, 1988: 116), it becomes necessary to turn to experiment and artistic modes of engagement. The consequence is what Bennett calls a politics of affirmation and enchantment, which replaces the always-already cynical task of demystification with a politics of wonder or a 'moment of methodological naiveté' (Bennett, 2010a: 17; for similar arguments see Latour, 2004). We are thus encouraged to embrace 'a less repressed, more cheerful way of engaging with the geographies of the world' (Woodyer, T. \& Geoghegan, 2012: 196). ${ }^{3}$

Whilst much of this vitalist agenda has been framed as fundamentally new to geography, it draws on much older debates. But whereas contemporary vitalist arguments have found inspiration in the work of biologists like Hans Driesch and Jakob van Uexküll or philosophers

\footnotetext{
3 There are echoes of this also in the insistence that (affirmative) geographical critique should display 'generosity towards the object of this critique' (McCormack, 2012: 726).
} 
like Henri Bergson, Gilles Deleuze or Georges Canguilhem, they have so far ignored vitalist geography. Contemporary neo-vitalists are perhaps not to blame for missing a vitalist strand within geographical thought, for Friedrich Ratzel's vitalism may have been written out of the history of vital materialism at a very early stage. Neither Driesch nor Bergson engage with Ratzel directly, and Georges Canguilhem only mentions him in passing (Canguilhem, 2001: 15). And yet, Ratzel's intellectual life was not detached from these vitalists.

Driesch and Ratzel were both students of the biologist and philosopher Ernst Haeckel whose monism was a major source of inspiration for the young Ratzel (Steinmetzler, 1956: 91), and both Ratzel and Driesch would later be published in the same book series with the publisher J. A. Barth. Friedrich Nietzsche, another source of philosophical inspiration for vitalism, had read Ratzel (Emden, 2008: 178) and Ellen Semple, Ratzel's disciple and populariser in the Anglophone world, was familiar with Henri Bergson and taught his vitalist theories alongside Ratzel's ideas in Oxford before WWI (Keighren, 2006: 533). Like many $20^{\text {th }}$ and early $21^{\text {st }}$ century vitalists, Ratzel was inspired by the ideas of Gottfried Wilhelm Leibniz and Baruch Spinoza, ${ }^{4}$ even if Ratzel did not pledge allegiance to the latter's pantheism (Buttmann, 1977: 102). Like Gilles Deleuze, Ratzel was moreover influenced by the philosopher and experimental psychologist Gustav Theodor Fechner who drove Ratzel's later work in the direction of panpsychism, the idea that consciousness inheres in the universe itself, and animism, the belief (sometimes spiritual) that life extends to inorganic materials (103). In what follows, I trace the shared intellectual ground between Ratzel's theory of life and contemporary vitalist geography.

Before we proceed much further, a health warning needs stating. Ratzel was writing in a very different intellectual climate and socio-political context than that of contemporary vitalists. He neither set up his materialism against social constructivist arguments nor did he recognise that researchers are never external to the processes they describe. Ratzel had no understanding of the micro-political and occasionally resorted to a language of 'higher' and 'lower' life forms. Perhaps more surprisingly, he ignored Karl Marx and the latter's historical materialism. Despite this highly different philosophical and historical context, we will see in the following section, Ratzel's political biogeography and contemporary neo-vitalism have striking ontological and epistemological overlaps.

\section{Re-reading Ratzel}

\footnotetext{
4 It is not easy to trace Ratzel's philosophical sources of inspiration because he had a tendency to be rather sloppy with his references.
} 
Born in Karlsruhe in 1844, Friedrich Ratzel began his career not as a geographer but as a pharmacist. It was only in 1866, at the age of 21, that the keen naturalist and collector of fossils managed to convince his parents to pay for him to study zoology and geology instead. After completing his studies, Ratzel spent time working as a research assistant, journalist and travel writer before signing up to serve in what would later be known as the $1870 / 71$ Franco-Prussian war. Ratzel was heavily injured in combat and spent much of the war in a military hospital where the former pharmacist became captivated by the medical power to foster and abandon the life of the wounded, an experience he would later return to in his writing (Ratzel, 1905). After the war, Ratzel resumed his academic work, moving first to the Universities of Munich and in 1886 to Leipzig. Ratzel was incredibly prolific over the course of his life and managed to publish around 30 books and over 1,ooo essays and shorter pieces (for a comprehensive bibliography see Helmolt, 1906).

We have already noted that Ratzel is known today primarily in the Anglophone world for his role in developing a set of ideas that would in the interbellum come to be known as geopolitics. This has most of all to do with the influence that Ratzel's political geography is often seen to have had on the formulation of Nazi ideology through Karl Haushofer. And yet, AngloAmerican geographers may already have thought of Ratzel primarily as a political geographer during his lifetime. Notably, for instance, Ratzel's obituary in Geographical Journal only noted his interest in nature in passing whilst focusing almost exclusively on his legacy to human geography (E. G. R., 1904). This is somewhat puzzling given that large parts of Ratzel's work are in fact biogeographical in vein, though almost none of this has, until recently at least (Ratzel, 1901[2018]), been available in English.

Ratzel made his first attempt at a theory of life in his dissertation Being and becoming in the organic world. Published in 1869, this early book was primarily an attempt to synthesise the ideas of Charles Darwin and his mentor Ernst Haeckel and suffered from a lack of originality, which Ratzel came to admit later in life. His subsequent travel writing and scholarship on political geography, however, started to reveal a thinker who was more confident in developing his own ideas. Ratzel returned to biogeography in the latter stages of his career as he became more interested in the philosophy of life. In this second biogeographical stage of his career, he advocated the idea of human geography as a branch of biogeography. In fact, Ratzel was working on a book, perhaps even a magnus opus, in the early 190os, which pursued this general biogeography, but which remained unfinished because of his premature death in 1904 . Nevertheless, he did leave posterity with a number of works which bring the contours of this theory of everything into focus, particularly his 1901 Lebensraum essay, his 1902 two-volume book 
Earth and Life, the 1904 The description of nature, and his posthumously published autobiographical Islands of happiness and dreams (1905). These works are the primary focus of the discussion that follows here.

Whether writing about the Migration Period of the first millennium AD or about obscure plants that only exist in one particular alpine valley, Ratzel was always trying to collapse binaries, including most prominently life/earth, space/time, life/death and human/non-human. Like contemporary more-than-human geographers, Ratzel argued that his endeavour was necessarily an interdisciplinary one, and he insisted that history needed biology and vice-versa. ${ }^{5}$ The trained zoologist may have mostly looked to biology for intellectual inspiration, but he was also happy to reverse the move and think about the animal and plant kingdom through a social lens. Ratzel's background in the natural sciences meant that he had a tendency to try to explain society by reference to the natural environment. And yet, Ratzel was not the environmental determinist he is sometimes made out to be. As Murphy argues, Ratzel was in the 1890 s 'becoming more, not less, wary about possible determinist implications in his understanding of the interaction between geographical setting and human agency' (Murphy, 2018: 90). ${ }^{6}$ The later Ratzel in particular is much better thought of as a vitalist who had become more preoccupied with the creative properties of life rather than with the iron grip of the environment over human society.

Firstly, Ratzel saw life as a creative, omnidirectional and insatiable force that was in continual motion and that resulted in constant 'change, development, deterioration' (Ratzel, 1905[1966]: 123).7 In his 1901 Lebensraum essay, he defined 'movement as a general characteristic of life' (Ratzel, 1901[2018]: 63). '[I]t overflows in all directions; its cause lies in the organism itself and no external factors are needed to activate its organic powers of movement'. Although he assumed all life to be made up of the same chemical compounds, he saw it as relentlessly producing an ever greater and more complex variety of organic materials (Ratzel, 1902b: 555). Ratzel located in this vitality the very logic that made space appear. Rather than operating with a simple Euclidian understanding of space, he conceptualised space as an outcome of the struggle for being and becoming. He saw a crucial tension between the expansive force of life

\footnotetext{
5 It is important to understand that it was not that Ratzel did not understand the distinction between biology and history, between physical and human geography. In fact, some of his works were written with very little commentary on physical geography at all. But rather, and much like today's vitalists, Ratzel attempted to deliberately fuse the humanities and the natural sciences.

${ }^{6}$ Indeed, it is difficult to imagine how a simplistic determinism would have appealed to someone like Carl Sauer who remained very positive about Ratzel, even after WWII (Sauer, 1971).

7 All translations are the author's.
} 
and the limits of the earth's surface. 'It is from this tension', he argued, 'that the struggle for space is born' (Ratzel, 1901[2018]: 72). 'Every increase in the organic mass, every growth, every reproduction' signified spatial movement, and every such movement was ultimately a 'mastering of space' (Raumbewältigung) (63).

'A plant's ramification and a coral's branching are cases of spacial expansion. The two-leaf germ of an oak, which barely takes up any space at all, grows into a tree of a thousand leaves whose shade is measured in square metres; the radially dividing and budding coral becomes a reef that forms a belt of 15 degrees of latitude off Australia's eastern coast; moss produces branches and shoots and, in the form of a peat bog, covers an area of thousands of square kilometres. Do we not have the right to ask whether the mastering of space is generally a manifestation of life and the hallmark of life?' (ibid)

There are even traces of a relational understanding of space in Ratzel: 'Clearly, space is something that lies outside the organism, and yet each living thing is bound to its space and connected to its space' (Ratzel, 1901[2018]: 71 original emphasis; see also Barua, 2018). Ratzel develops this dynamic understanding of space through the notion of the oecumene, which denotes an ever evolving and temporary configuration of inhabited space. In this sense, Ratzel's concept of the oecumene tries to trace the relations between human movement and the earth over time, patterns that are inherently difficult to depict cartographically because of the way in which they co-produce one another (Santini, 2017).

Ratzel used this understanding of life-in-motion to grapple with the behaviour of human groups. Like all other life forms, nations (Völker) had to secure their livelihood either by means of territorial expansion, colonisation or migration. Large spaces, he held, made for more creative life than small ones. Ratzel famously argued in his 1897 Political Geography that the state too was an organism in the sense that it was rooted in its soil on which it depended and in which its inhabitants would one day be buried (Ratzel, 1897[1923]). Crucially, he thought of this organism as having organs which could exist independently of one another and able to separate and form new polities. ${ }^{8}$

Secondly, Ratzel was a monist who saw life and earth as existing in fundamental unity. He proposed an 'organic understanding' of the earth, which approached the latter as a whole,

\footnotetext{
${ }^{8}$ New materialists have sought to delineate between vitalism and organicism (Dittmer, 2014: 387; DeLanda, 2006: 89). And yet, Ratzel's state-as-organism is made up of organs that can explicitly be both dis- and reassembled.
} 
including its crust, hydrosphere, atmosphere and biosphere. He also stressed the 'telluric unity of life', the idea that life was earthbound (Ratzel, 1902b: 549). Ratzel spoke of the earth itself as organic, for he saw traces of life as scattered throughout the planet, often 'mixed up with inorganic materials' to a degree that it would be problematic to separate them out (Ratzel, 1902a: 504). Even the most inhospitable climatic conditions were able to host life forms and were therefore not fundamentally alien to life - he wrote at a time when exploration of deserts, oceans and mountains were revealing new evidence of extreme life. Like Darwin, he was interested in the geologic forces and decomposition processes of small life forms which made the earth ready to carry new life. He saw this intertwining of life and earth not merely in competitive terms but as mutual cooperation, in which organic and inorganic forces conspired to make possible each other's existence. Ratzel was fascinated, for instance, by shells whose attachment to cliffs secured the latter from waves, by plants that were so interwoven that they helped to support the earth, and by species whose livelihood rested in the faeces of other species.

Already as a child, Ratzel had held the conviction that there was no meaningful distinction between life and death and he reiterated this belief posthumously (Ratzel, 1905: 201). His attempt to dissolve the organic/inorganic binary meant that Ratzel was at times flirting with a form of animism:

'I see all life forms in a landscape, the many trees and plants, which are scattered in groups across it; with the idea in mind that life is movement, I see them as wandering, striving together and dispersing. That mountain there seems to me alive, its trees seem to be moving, some of them striving upwards, others descending. Some rear their heads upwards, others creep away into the earth' (Ratzel, 1904[1923]: 125)

Read this in the context of Povinelli's more recent return to animism, in her case the insistence that a mountain can 'turn her back' upon the world of humans and their settler liberalism (2016: 56). Under the influence of the aforementioned Fechner, Ratzel too came to believe that life was not restricted to the earth but that it inhered in the movement of celestial bodies (Steinmetzler, 1956: 138). Although Ratzel did not speak of an élan vital, he came to believe that the ocean had a 'spirit' and that in 'each thing of nature inhered a divine aspect' (Ratzel, 1901b: 239).9

Thirdly, Ratzel sought to move beyond anthropocentrism by showing how human existence was neither unique nor independent from the geo and the bio. Much like

\footnotetext{
9 Ratzel also returned to his Christian belief in the latter stages of his life after having abandoned it in his youth.
} 
contemporary vitalists, Ratzel resorted frequently to anthropomorphisms to make sense of the animal and plant kingdoms. According to Ratzel, life forms were not simply able to enter into a variety of parasitic or symbiotic relationships, but could themselves form societies that were not dissimilar to human groups. Ratzel was of course primarily thinking of herds of mammals but he also spoke quite casually of certain animal species as 'citizens' or as living in 'colonies', and suggested that 'overpopulation' occurred in nature as much as in society (colonisation and overpopulation being key concepts in his human geography, too). Ratzel had a sense for the way in which humans and non-humans had cooperated over time, such as in the domestication of animals. He noted, with a good degree of admiration, how the brown rat was 'so cosmopolitan that it manage[d] to gain a foothold wherever European boats had passed even if only fleetingly' (Ratzel, 1881: 338). Many of Ratzel's creatures were moreover able to 'act' like humans, even use technology. He was enchanted by spiders that could be found 'wafting more than $100 \mathrm{~km}$ across the sea [] like miniature balloons: a small spider sits in the gondola, i.e. at one end of the web, thus making its journey' (Ratzel, 1901[2018]: 64).

This willingness to read non-human life through a human and social lens gave Ratzel's geography the whiff of what we might today call a post-humanist spirit. In his first book he had already explained that there was 'no fundamental difference between moss, infusoria and humans, only differences of degree' (Ratzel, 1869: 482; compare to Deleuze, 1988: 101). Although humans had attempted to master the earth, they were ultimately but an effect of the natural world. 'The earth has everything that humans have', Ratzel would write later, 'because it has humans themselves' (Ratzel, 1905: 506). Whilst Ratzel initially held on to the notion that humans were in something of an 'exceptional position' in comparison to other life forms, due to their capacity for language and their 'highly developed spirit', he emphasised that humans were not 'alien' to the earth and should therefore not be treated in isolation from other life forms.

Ratzel had a tendency to move his discussion from larger to smaller scales. He would typically start with astronomy, then move on to geology before turning to physical geography and biogeography. Only once he had completed this voyage through time and space would he finally address questions of a distinctly human geography. The consequence of this move was a worldview which placed humanity in a key position, at the end of the story, and yet also rendered it insignificant in relation to the cosmic and planetary forces that made up the bulk of the discussion. Although the human mind was unique in its capacity for reflection, the human body, Ratzel was convinced, was ultimately governed by the same principles as all other life forms. Moreover, as he was never tired of reminding his readers, humanity was dependent on 
the animal and plant kingdoms in its quest for nutrition and shelter (Ratzel, 1902b: 556-557). Despite the fact that humans had been able to fundamentally alter the biosphere (Ratzel noted forest degradation and hydraulic engineering amongst other human impacts), he was keen to stress that human beings were in a fragile position vis-à-vis storms, volcanic eruptions and the inevitability of the passing of time (Ratzel, 1881: 429). Ultimately, humanity was 'but a grain of dust' compared to the forces of nature (Ratzel, 1901b: 247).

The degree to which Ratzel was willing to think even about that most human of spheres - culture - in post-humanist terms can be seen from his treatment of art. The latter, he felt, was but 'the highest and most blossoming shoot of nature' (249). Nature, he observed with considerable admiration, 'encloses art, invades it from all sides, grows together with it' (250). 'What else is the whole history of fine art', he asked, 'but a variation of motives that nature provides?' (ibid). Indeed, he was even willing to argue that the artist 'was himself nature', simply representing the forces of nature. In this sense there was already 'style', he claimed, in landscapes that no artist had ever seen (Ratzel, 1904[1923]: 137; 249; compare this to Grosz, 2009; see also critical reception of these ideas in Ingram et al., 2016).

Fourthly and finally, Ratzel was keen to produce geographical knowledge that privileged direct experience. Unlike common belief, he was not in fact a positivist and treated laws as 'complex, probabilistic and very un-Newtonian statements of general tendency' (Smith, 1980: $52)$. He thought that geography had to be experienced, whether it was a volcanic eruption or the noises that a human settlement makes at night (think of chains that gently rattle in a barn). Towards the end of his life, Ratzel had reached the conclusion that science had its limitations and that 'geographical description [was] not a purely scientific but to a large degree an artistic task' (Ratzel, 1904[1923]: 8). This finding chimed with a creative streak and a vivid imagination that even some of his admirers referred to as a 'tendency to speculation' (Wanklyn, 1961: 38). By the end of his life, Ratzel had recognised that he was as much a scientist as a popular writer. Not only was he a travel writer, but he was also versed in literature and fine art and produced the occasional Romantic poem, too. Whilst his autobiography was explicitly written as a hybrid of fiction and non-fiction, his 1904 book The description of nature was meant as 'an introduction to an artistic or aesthetic geography in the sense of a synthesis of literary and scientific representation' (Buttmann, 1977: 107).

Ratzel wanted geography-as-art not to remain 'a slave to reality' but to bring out nature's beauty by 'presenting the truth with force and wealth' (Ratzel, 1904[1923]: 33). ${ }^{10}$ Observation was

\footnotetext{
${ }^{10}$ Note that Ratzel had no sense of historical change in aesthetic regimes, he simply wanted to determine the laws of aesthetics.
} 
obviously crucial to his method, but he also proposed ways of feeling and listening to the rhythms of nature. It was clear to him that the geographer had to 'feel himself [sic] into the landscape' (sich in die Landschaft hineinfühlen). Indeed, he emphasised the necessity of a certain 'naivety and imagination' (34) and held that most people were too driven by reason. Their felt experience (Empfinden), he was convinced, was far superior to their capacity for rational reflection (64). In an almost contemporary vein, Ratzel wrote that landscape description should seek to reproduce a certain 'atmosphere that hovers over nature and the work of humans in nature' (Ratzel, 1904[1923]: 16 emphasis added). In his autobiographical essays he moreover wanted to capture the physical sensation of having experimented with intoxication when working as a young pharmacist. The following slightly hallucinogenic passage illustrates how he tried to showcase the vitalist themes of his work in the register of corporeal experience:

\footnotetext{
'Why shouldn't I try it, to fly? Here it stands in a stone jar, that cherry laurel, a liquid whose prussic acid lends it a biting but elegant scent. I am not frightened by the skull above the archaically ornamented label "Aqua Laurocerasi". The hydrogen cyanide content is not all too strong. Perhaps its effect will just be anaesthesia, dream and return, but perhaps it is death. What difference does it make? And here is an old glass of Bohemian crystal, the clarity of which I have long admired. How innocent that blueish venom shimmers. A long sip, a second, I can already feel my hands tremble...' (Ratzel, 1905, [1966]: 74).
}

Ratzel awakes only after days, his 'limbs broken, head dull, but with an unquestionable awareness of life [Lebensgefühl]'.

Despite his intention to write his autobiography through both fiction and non-fiction, the experience could well be interpreted as a suicide attempt. Ratzel noted his realisation, when recovering, that there were human beings in the world who valued him, and he was left feeling guilty and repentant. But what matters even more than Ratzel's personal near death experience is perhaps the language of Romanticism in which the episode is rendered. Death, he concluded, was possibly 'the most beautiful thing that can be thought' (73). Underlying this restlessness is a longing to be enchanted, to be immersed by a naïve disposition of wonder. 'How great is a child's reality', he asked, 'how much more does it own and master because it has the wonderful' (Ratzel, 1905[1966]: 23 emphasis added). 
This expression of wonder resides side by side with some rather different political commitments. For whilst Ratzel was, unlike many of his contemporaries, neither particularly anti-Semitic nor misogynist, he was a keen supporter of German colonialism in Africa. Although he explicitly rejected the biological racism of Chamberlain and Gobineau (Ratzel, 1906; see also Bassin, 1987), he tried to naturalise forced labour and slavery with reference to climatic conditions (Ratzel, 1902b: 543; see longer discussion in Schultz, 2006). Indeed, he thought of North America's black population as 'animal-like' (zoo-politics) and proposed that it be resettled in Africa or the West Indies (Ratzel, 1876[1988]: 211; 170). His three-volume History of Mankind (published in German 1885-1888) is deeply infected with a colonial form of racism that interpreted practices such as cannibalism and infanticide amongst so-called 'primitive people' as signs that these weaker people were self-exterminating and making way for the superior white settlers (Klinke, 2018a).

Crucially, his political positions were not just tagged on to his theory but emerged from his vitalism and monism. Interestingly for instance, Ratzel's human and bio-geography had never rigidly distinguished between extinction and extermination. He had moreover no sadness for a species or race that was wiped off the earth's surface for it had proven inferior in the struggle for space. ${ }^{11}$ Incidentally, Ratzel's Lebensraum piece was published only shortly before the German empire's genocide of the Herero in what is now Namibia. War and extermination, for Ratzel, were natural and necessary processes. Nations that settled down and forgot about this would eventually be subdued and annihilated by others. This is not to claim that Ratzel directly inspired the colonial violence of Wilhelmine Germany but it is to highlight the way in which his ideas could be read as providing scientific legitimacy for colonial violence and war. It is particularly this question of organised killing that demands further attention.

\section{Vitalism and war}

For what might happen if we take vitalism to the phenomenon of war? Interestingly, geographers who have recently flirted with a vitalist perspective on war have either a) remained broadly committed to an anthropocentric approach (Forsyth, 2016), b) have sought to limit nature to its role as a 'medium through which military and paramilitary violence is conducted' (Gregory, 2016: 4) or c) have avoided discussion of the concept of war altogether (Johnson, 2015). This may not be a coincidence. Indeed, it is not easy to find a truly vitalist account of war. Deleuze and Guattari, perhaps a logical starting point on such a quest, make an argument about

\footnotetext{
${ }^{11}$ For a discussion of the implication of other $20^{\text {th }}$ century vitalisms with racial discourse, see Jones, 2010
} 
an age-old conflict between the war machine and the state, in which the latter tries to ward off the former. ${ }^{12}$ Whilst the war machine is rooted in nomadic social organisation, the state has its roots in the emergence of Indo-European sovereignty (Deleuze and Guattari, 1986; Reid, 2003). These arguments are highly transhistorical in nature and based on an unproblematised treatment of 'Indo-European civilisation', a notion Deleuze and Guattari take from the French philologist George Dumézil. ${ }^{13}$ Crucially, however, their concept of war is too anthropocentric and social in nature to qualify as fully vitalist, at least according to the definition laid out in this article. If, however, we venture back into Friedrich Ratzel's writings on war, we find a much more consistently vitalist concept of war.

War, to Ratzel, was no different from other phenomena such as migration or traffic, which he saw as expressions of the same creative and expansive properties of life that could be observed in the animal and plant kingdoms - struggle, conquest and colonisation. And yet, war was special in that it was the origin of superior spatial consciousness amongst humans; war was 'a great school for the faculty of mastering space'. This 'mastery over space' brought humans 'every moment face to face with the things of nature', resulting in 'a literal and material tendency of thought' (Ratzel, 1898: 450, 457). In Ratzel's reading, war was thus the medium through which nature, Whatmore's (2005: 15) 'creative energies of the earth itself, in rivers, soils, weather and oceans', imposes itself onto spatial consciousness. It is in this light, that Ratzel described the eve of the 1870/71 Franco-Prussian war as a sweltering thunderstorm (Gewitterschwüle), which loomed over the lecture theatres, driving enthusiastic students into battle. This overwhelming passion for war was still palpable thirty years later in a collection of essays that formed his war memoires and that would be published in Islands of happiness and dreams (Ratzel, 1905). It was here that Ratzel lamented shortly before his death that it was 'a shame that there are not more wars' (139).

Ratzel's account of the Franco-Prussian war displays a tendency to fuse immersive descriptions of war both with detailed landscape depiction and with the metaphorics of nature. His observations are carefully attuned to the perception of the sensing human body; the reader hears, smells, feels and tastes the war with his protagonist. Ratzel portrays in detail the muddy trenches in which he is forced to lie and speaks of soldiers as 'trees within the forest of his people

\footnotetext{
${ }^{12}$ Jane Bennett (2010b: 57) mentions war in passing in her discussion of what she calls 'the latter day vitalism' of the George W. Bush administration, which she delineates from her own brand of vitalist materialism. She does not attempt to think war through systematically from a vitalist perspective.

13 Dumézil would later come to retract some of these ideas. Note also Weizman's (2007: 200) discussion of Israeli military strategy's flirtation with Deleuze.
} 
[Volk]' (120, and again 133). Civilians are struck dead by 'lightning bolts' (231, 259), discipline 'takes root' in the young soldier (145) and the rifle drill movement lets the technology of the weapon itself 'be absorbed by the human body and psyche' (147). War emerges thus as a form of hybrid nature, where non-human agencies act upon and shape the body and mind of the combatant; nature itself seems to be at war.

Ratzel's narrative is also marked by a notably detached depiction of the horrors of war, which treats the latter with medical detail but without overt emotional or indeed political undertones. In this, I would argue Ratzel's war narrative prefigures the infamous and deeply experiential account of WWI trench warfare given in the 1920 bestseller Storm of Steel by Ernst Jünger, one of the Third Reich's literary heroes. Both accounts, published only 15 years apart, are graphic in nature and place the human subject within a larger technological and environmental assemblage in which mud, shrapnel, bloodied uniforms and torn off limbs come together in a kind of more-than-human dance that performs the spectacle of war. ${ }^{14}$ Most importantly however, Jünger, much like Ratzel, describes war as a natural rather than a social force. Jünger's trench world is one of insects, colourful flowers and elementary forces, of 'hurricanes of fire' and 'hails of shells' (Huyssen, 1993: 15), a stylistic move that continues to draw admiration from some contemporary political geographers (Gregory, 2015; 2017). Given the semblance between Ratzel and Jünger's texts, it is perhaps unsurprising to learn that much like Ratzel, Jünger was a keen biologist, indeed an entomologist. He was also a student of the very vitalist who continues to inspire a new generation of vital materialists, the aforementioned Hans Driesch (Bennett, 2010a).

Much can be said about the bio-physical entanglements of fragile human bodies with the hostile environments of the trench, the jungle or the desert, about the ways in which nonhuman agents and elementary forces come to matter on the battlefield, from the war horse to the virus and from the chemical agent to a simple change in weather conditions. War memoires like Ratzel's and Jünger's have long been filled with such stories. And yet, it may not be a coincidence that contemporary geographers have shied away from a truly vitalist concept of

\footnotetext{
14 There are significant stylistic differences between Jünger's machinegun length sentences and Ratzel's more romantic prose, and yet, both Jünger and Ratzel aestheticise war, even its horrors. Ratzel refers to the latter as the 'aesthetics of the ugly' (Ratzel, 1905: 197). Both writers interpret the soldier not just as a final arbiter in conflict but as a subject whose metamorphosis from naïve and confused civilian to masculinised warrior is completed only in the experience of war. This commitment to masculine subjectification does not derive directly from the belief in the creative energy of life, but it does anticipate the warrior myth that would come to dominate German political discourse in the interbellum.
} 
war, for such a move would confer onto nature at least some of the properties that are otherwise, and for very good reasons, thought of as those of a social institution.

For whilst Ratzel insists that war is but a transhistoric epiphenomenon of the creative properties of life itself, he does not grasp that war relies on basic conventions which evolve significantly over time (Grayling, 2017; Kaldor, 2012). Despite the seemingly unharnessed aggression that war can unleash, it is fundamentally a social institution that relies on the production of intersubjective meaning and processes of signalling between antagonistic social groups; even so-called asymmetrical warfare is governed by a complex web of legitimacy and recognition. Modern war relies on sophisticated bureaucratic, economic and emotional economies. The basic social nature of war was already acknowledged in the early $19^{\text {th }}$ century by one of Ratzel's sources of inspiration, the Prussian military strategist Carl von Clausewitz (1989[1832]). Of course, natural forces can produce harm to the human body on the battlefield, but this is not to say that these agencies have the capacity to wage war. Nature thus does not go to war, it does not 'assault' us, as Gregory (2016: 35 ) notes perhaps a little too carelessly, unless of course we choose to deny, neglect or side-line this social essence of war. Similarly, to speak of 'geologic violence' (Clark, Gormally \& Tuffen, 2018: 282), is to remove from the meaning of violence questions of intentionality and emotional investment. Such a radical departure from the conceptual status quo may seem enticing to some, but it could only be claimed to be novel if Ratzel's vitalist geographies were continued to be ignored.

A fully vitalist concept of war would also come at a certain political cost; if humans are indeed caught up in assemblages of war which are defined and confined by powerful material agencies, then it is unclear how humans extricate themselves from these powerful entanglements of nature, technology and flesh (Lemke, 2018: 13). How, in other words, can we account for the sudden urge for peace if the question of ideology is declared uninteresting? It surely is difficult to comprehend militarism, for instance, as anything other than thickened ideology, which has entered into the most capillary social practices, mobilising bodies and materials, but not the other way around.

This links up with a second problem, which is the locus of responsibility. For if nature can wage war, then this raises the question of who is to blame for war's emergence. Is it a surprise that Ratzel, who took vitalism considerably further than geography's current infatuation with life's creative properties, was incurious towards the very social structures that had made the war in which he had fought possible in the first place? Is it a coincidence that Ratzel was ultimately enchanted by the techno-aesthetics of battle to the degree that he would come to hail war as the creator of space itself? All of this indicates that contemporary vitalism's 
distinction between a (bad) politics of agonism and a (good) politics of enchantment does not hold. In the vitalist work of the late Ratzel, echoing back to us from the bellicose fin-de-siècle (Heffernan, 2000), we can find both a romantic voice of wonder and an agonist understanding of politics in surprising harmony.

Whilst stories about the socio-materiality of war certainly must not be left to reactionary military historians, these stories need to be told precisely in ways that keep intact a sense of war as a set of social practices. Friedrich Ratzel saw war as a medium through which nature imposed itself on spatial consciousness, an idea which was inextricable from his own militarism. The ways in which Ratzel's vitalist concept of war chimes with Ernst Jünger's proto-fascism is not coincidental and merits further discussion of vitalism's entry into Anglophone political geography. This is not to say that all vitalism has slumbering within it a proto-fascist political project but it is to say that there are problems here. There is, for instance, the issue of the language that vitalism uses in order to navigate, indeed blur, the boundary between nature and society. Although it has been common for vitalists to anthropomorphise non-human agents (Bennett, 2010a: 120), vitalism has not been willing to reverse this move and conceptualise phenomena such as war in the terms of its own theory. If the concept of geopolitics, to which Ratzel's disciples gave birth, is indeed rehabilitated (Clark, 2013), then this seems a task of primary importance.

Of course, it is now fairly uncontroversial to understand war as an assemblage of bodies, ideas, materials and technologies - but it is less clear how we might bring to bear the notion of vitality on something as crucial as militarism or state violence. It is puzzling that a monist theory, which, if taken to its logical conclusion, must end up a theory of everything, has so far been rather mute on this question.

\section{Vitalism and the birth of biopolitics}

This brings me finally to the question of vitalism's own place within the history of political thought and practice, a point raised by Gandy and Jasper (2017). And whilst we may agree that there are limits to the conceptual work that a Foucaultian biopolitics can do to aid our understanding of anthropocentric late liberalism (Povinelli, 2016), such biopolitics is able to help us understand the gaze that Ratzel's vitalism and other historical vitalisms perform onto the nature/society nexus.

For can we not read Ratzel's vitalism as a way of making sense of the fin de siècle's instability and competitive nature through the prism of biological and political life? For the consequence of understanding life as insatiable and creative is of course that nothing in the 
world is solid and everything melts into air. Whilst at first sight, Ratzel's biopolitics may seem very different from that articulated by Michel Foucault $(1976 ; 1978)$ and Ratzel certainly never developed his theory of life as a critical conceptual tool, it is certainly possible to read Ratzel as a biopolitical thinker (Minca, 2006; see also Lemke, 2011: 13; Klinke, 2018a). Ratzel, for instance, was aware of the two scales that Foucault would later designate as crucial to his understanding of biopolitics - the population and the human body - and developed in his later work an interest in the conditions of life, such as light, air, warmth and moisture on both the human body and on whole nations and their desire to migrate (Ratzel, 1902b: 530).

Ratzel admired North America for its love of statistics and its tendency in the late $19^{\text {th }}$ century to carefully compile data on public health, living conditions and mortality rates. On his travels to the United States he noted in appreciation the way in which North American society had managed to control smallpox through inoculation and was fascinated by American architects' and urban planners' concern for ventilation and cleanliness (Ratzel, 1876[1988]: 33). Moreover, he had a sense of how bodies became the subject of governmental practices, particularly in times of war. Upon his entry into the Prussian army, Ratzel had become aware of the way in which modern war required him to cast away his identities as a civilian and scientist and subject his body to the biopolitics of the war machine. 'The fatherland', he wrote, 'needs nothing other than our naked bodies; just as we stand in front of the army doctor, this is how one wants us: legs for marching and arms to shoot and punch, a body that holds these together and a head with the right senses, nothing else is required' (Ratzel, 1905: 133). Note not just the way in which Ratzel reduced the social function of the Prussian soldier to a body that has the 'right' visceral experience of war, but also his unwillingness to think of the soldier as a moral or political being. Ratzel's soldier, in other words, was not a subject of ideology.

In this sense, the geographical vitalism of Ratzel, with its obsession for immanence, could be read as part of a wider shift in the history of government. It is hardly a coincidence that it was the glowing Ratzelian Rudolf Kjellén who coined the term biopolitics (Kjellén 1920: 94). If the popularity of vitalism at the turn of the $2 \mathrm{O}^{\text {th }}$ century is read as an expression of that historical context, then it is perhaps unsurprising that the $20^{\text {th }}$ century sought to govern it by categorising and sorting it, fostering and abandoning it - as witnessed both in Nazi and Cold War biopolitics (Klinke, 2018b). Unknowingly, Ratzel was providing a scientific, philosophical and poetic language with which to think through a politics of life and earth, even if other, though not entirely dissimilar, languages ultimately proved more impactful. As Simon and de Goede (2015) have shown, vitalism can rather easily itself be taken up by a governmental gaze that attempts to control the unpredictable processes that emerge from and endanger the vital 
conditions on which modern society depends. Ratzel's vitalism can thus be read as something of a primordial soup for a whole range of political ideas that would come to haunt the $20^{\text {th }}$ century.

If geography's current flirtation with vitalism is to develop a more convincing political fundament, it will have to re-engage with the darker materialisms in the history of political geography and the wider geographical tradition. This is not to suggest that contemporary work that displays a vitalist temptation simply replicates Ratzel. It would be difficult to find a geographer today who reduces the complexities of world politics to that of a zero-sum dynamic, as it is often (though not always) the case with the founding father of political geography. And yet, a contemporary geographical temptation to collapse the question of meaning into matter, to side-line social structure and ideology whilst opening the political up to a wide variety of non-human agencies, does chime with Ratzel's political biogeography.

Finally, a point on ontology. It has recently become popular amongst post-humanists to argue that colonial violence rests on and works through dualistic nature/society constructions and that monism and animism, inspired perhaps by various indigenous cosmologies, might be drawn upon as forms of intellectual resistance against colonial Eurocentrism (Povinelli, 2016; Sundberg, 2014). And yet, in Ratzel we find a thinker who was a monist, an animist and an advocate for settler colonialism. Indeed, his entire intellectual project was one of imploding binaries such as life and death, space and time. The misanthropy that sometimes underwrites contemporary materialist scholarship could be a starting point for further discussion. For like today's vitalists and animists who have found solace in the vision of a planet 'that will still be here when we are not' (Povinelli, 2016: 176), Ratzel was mesmerised by a world of fossils and human ruins. He too was enthralled by the fantasy of a landscape whose beauty lay in the eerie absence of human but not all life. 


\section{Bibliography}

Abrahamsson, C. (2011). Book review forum: Vibrant Matter: A Political Ecology of Things. Dialogues in Human Geography 1: 399-402.

Abrahamsson, C. (2013). On the genealogy of lebensraum. Geographica Helvetica 68: 37-44.

Barua, M. (2018). Ratzel, bio-geography and the more-than-human. Journal of Historical Geography 61: 102-108.

Bassin, M. (1987). Race contra space: the conflict between German geopolitik and National Socialism. Political Geography 6: 115-134.

Bennett, J. (2010a). Vibrant matter: A political ecology of things. Durham and London: Duke University Press.

Bennett, J. (2010b). A vitalist stopover on the road to a new materialism. In D. Coole and S. Frost (Eds.) New materialisms: Ontology, agency, and politics. Durham and London: Duke University Press, 47-69.

Bennett, J. (2011). Author response. Dialogues in Human Geography 1: 404-406.

Bergson, H. (1911[1983]). Creative evolution. Lanham: University Press of America.

Braun, B. (2008). Environmental issues: Inventive life. Progress in Human Geography 32: 667679 .

Braun, B. (2011). Book review forum. Dialogues in Human Geography 1: 391-393.

Bregazzi, H. R. and Jackson, M. S. (2016). Agonism, critical political geography, and the new geographies of peace. Progress in Human Geography 42: 72-91.

Buttmann, G. (1977). Friedrich Ratzel: Leben und Werk eines deutschen Geographen. Stuttgart: Wissenschaftliche Verlagsgesellschaft MBH.

Canguilhem, G. (2001). The living and its milieu. Grey room 3: 6-31.

Castree, N. (2011). Review of Vibrant matter by Jane Bennett, Society and Space, at http://societyandspace.org/2011/og/14/vibrant-matter-a-political-ecology-of-things-byjane-bennett-reviewed-by-noel-castree/ [accessed 26 July 2017].

Clark, N. Gormally, A. \& Tuffen, H. (2018). Speculative volcanology: Time, becoming, and violence in encounters with magma. Environmental Humanities 10: 273-294.

Clark, N. (2013). Geopolitics of the threshold. Political Geography 37: 48-50. 
Coole, D. and Frost, S. (2010). Introducing new materialisms. In D. Coole and S. Frost (Eds.) New materialisms: Ontology, agency, and politics. Durham and London: Duke University Press, 1-43.

Cresswell, T. (2012). Review essay: Nonrepresentational theory and me: notes of an interested sceptic Environment and Planning D 30: 96-105.

DeLanda, M. (2006). A new philosophy of society: Assemblage theory and complexity. London and New York: Continuum.

Deleuze, G. (1988). Bergsonism. New York: Zone Books.

Deleuze, G. and Guattari, F. (1986). Nomadology: The war machine. New York: Semitext(e).

Dittmer, J. (2014). Geopolitical assemblage and complexity. Progress in Human Geography 38: $385-401$.

Dittmer, J. (2017). Diplomatic material: Affect, assemblage and foreign policy. Durham: Duke University Press.

Dodds, K. and Atkinson, D. (200o). Geopolitical traditions: A century of geopolitical thought. London: Routledge.

E. G. R. (1904). Obituary notice of Friedrich Ratzel. The Geographical Journal 24: 485-487.

Elden, S. (2017). Foucault and geometrics. In P. Bonditti, D. Bigo and F. Gros (Eds.) Foucault and the modern international: Silences and legacies for the study of world politics. Basingstoke: Palgrave, 295-311.

Emden, C. (2008). Friedrich Nietzsche and the politics of history. Cambridge: Cambridge University Press.

Farinelli, F. (2000) Friedrich Ratzel and the nature of (political) geography. Political Geography 19: $943-955$.

Fraser, M., Kember, S. and Lury, C. (2005). Inventive life: Approaches to the new vitalism. Theory, Culture and Society 22: 1-14.

Forsyth, I. (2016). More-than-human warfare. Social and Cultural Geography 17: 798-802.

Forsyth, I. (2017). A bear's biography: Hybrid warfare and the more-than-human battlespace. Environment and Planning D 35: 495-512.

Foucault, M. (1976). Society must be defended: Lectures at the Collège de France, 1975-1976. New York: Picador. 
Foucault, M. (1978). The History of Sexuality Part I: The Will to Knowledge. London: Penguin.

Gandy, M. and Jasper, S. (2017). Geography, materialism, and the neo-vitalist turn. Dialogues in Human Geography 7: 140-144.

Ginn, F. (2014). Sticky lives: Slugs, detachment and more-than-human ethics in the garden. Transactions of the Institute of British Geographers 39: 532-544.

Greenhough, B. (2010). Vitalist Geographies. In B. Anderson and P. Harrison (Eds.) Taking Place: Non-representational Theories and Geography. Farnham: Ashgate, 37-54.

Grayling, A. C. (2017). War: An inquiry. New Haven and London: Yale University Press.

Gregory, D. (2015). Gabriel's map: Cartography and corpography in modern war, In P. Meusburger et al. (Eds.) Geographies of knowledge and power. Dordrecht: Springer: 89-12. Gregory, D. (2016). The natures of war Antipode 48: 3-56.

Gregory, D. (2017). Periscope, available at https://geographicalimaginations.com/2017/og/20/periscope-2/ [accessed 29 May 2018].

Grosz, E. (2008). Chaos, territory, art: Deleuze and the framing of the earth. New York: Columbia University Press.

Harrison, P. (2015). After affirmation, or, being a loser: On vitalism, sacrifice, and Cinders. GeoHumanities 1: 285-306.

Heffernan, M. (2000). Fin de siècle, fin du monde? On the origins of European geopolitics, 18901920, In K. Dodds and D. Atkinson (Eds.) Geopolitical traditions: A century of geopolitical thought. London: Routledge: 27-51.

Helmolt, H. (1906). Kleinere Schriften von Friedrich Ratzel, 2. Band. München: R. Oldenbourg.

Herwig, H. (2016). The demon of geopolitics: How Karl Haushofer "educated" Hitler and Hess. Lanham: Rowman and Littlefield.

Ingram, A. et al. (2016). Beyond geopower: Earthly and anthropic geopolitics in The Great Game by War Boutique. Cultural geographies 23: 635-652.

Johnson, E. R. (2015). Of lobsters, laboratories, and war: animal studies and the temporality of more-than-human encounters. Environment and Planning D 33: 296-313.

Jones, D. V. (2010). The racial discourses of life philosophy: Négritude, vitalism and modernity. New York: Columbia University Press.

Jünger, E. (2004[1920]). Storm of Steel. London: Penguin. 
Kaldor, M. (2012). New and old wars: Organised violence in a global era. Cambridge: Polity.

Keighren, I. M. (2006). Bringing geography to the book: Charting the reception of Influences of geographic environment. Transactions of the Institute of British Geographers 31: 525-540.

Keighren, I. M. (2018). History and philosophy of geography III: The haunted, the reviled, and the plural. Progress in Human Geography [online first].

Klinke, I. (2018a). Friedrich Ratzel, Lebensraum and the death motif. Journal of Historical Geography 61: 97-101.

Klinke, I. (2018b). Cryptic concrete: A subterranean journey into Cold War Germany. Oxford: WileyBlackwell.

Lash, S. (2006). Life(vitalism). Theory, Culture and Society 23: 323-349.

Latour, B. (2004). Why Has Critique Run out of Steam? From Matters of Fact to Matters of Concern. Critical inquiry 30: 225-248.

Lemke, T. (2011). Biopolitics: an advanced introduction. New York and London: NYU Press.

Lemke, T. (2018). An alternative model of politics? Prospects and problems of Jane Bennett's Vital Materialism. Theory, Culture and Society [online first].

McCormack, D. (2012). Geography and abstraction: Towards an affirmative critique. Progress in Human Geography 36: 715-734.

Minca, C. (2006). Giorgio Agamben and the new biopolitical nomos. Geografiska Annaler: Series B 88: $387-403$.

Müller, G. H. (1996). Friedrich Ratzel (1844-1904), Naturwissenschaftler, Geograph, Gelehrter. Stuttgart: GNT Verlag.

Murphy, D. T. (2017). "Retroactive effects": Ratzel's spatial dynamics and the expansionist imperative in interwar Germany. Journal of Historical Geography 61: 86-9o.

Osborne, T. (2016). Vitalism as pathos Biosemiotics 9: 185-205.

Ó Tuathail, G. (1996). Critical geopolitics: The politics of writing global space. Minneapolis: University of Minnesota Press.

Philo, C. (2007). A vitally human medical geography? Introducing George Canguilhem to geographers. New Zealand Geographer 63: 82-96.

Philo, C. (2017). Guest editorial: Less-than-human-geographies. Political Geography 60: 256-258.

Povinelli, E. (2016). Geontologies: A requiem to late liberalism. Durham: Duke University Press.

Protevi, J. (2012). 'Deleuze and life', in H. Somers-Hall and Daniel W. Smith (eds) Cambridge 
Companion to Deleuze. Cambridge: Cambridge University Press, 239-264.

Ratzel, F. (1869). Sein und Werden in der organischen Welt: Eine populäre Schöpfungsgeschichte. Leipzig: Gebhardt und Reisland.

Ratzel, F. (1876[1988]). Sketches urban and cultural life in North America. New Brunswick and London: Rutgers University Press.

Ratzel, F. (1881). Die Erde in vierundzwanzig gemeinverständlichen Vorträgen über Allgemeine Erdkunde. Stuttgart: J. Engelhorn.

Ratzel, F. (1885[1896]). The history of mankind, Volume I. London: MacMillan.

Ratzel, F. (1897[1923]). Politische Geographie. München und Leipzig: R. Oldenbourg.

Ratzel, F. (1898). Studies in political areas II: Intellectual, political, and economic effects of large areas. American Journal of Sociology 3: 449-463.

Ratzel, F. (1901[2018]). Lebensraum - a biogeographical study (translated by Tul'si [Tuesday] Bhambry Journal of Historical Geography 61: 59-80.

Ratzel, F. (1901b). Der Geist, der über den Wassern schwebt. In H. Helmolt (ed) Kleinere Schriften von Friedrich Ratzel, herausgegeben von Hans Helmolt, 1. Band. München: R. Oldenbourg, 237-249.

Ratzel, F. (1902a). Die Erde und das Leben, 1. Band. Leipzig und Wien: Bibliographisches Institut.

Ratzel, F. (1902b). Die Erde und das Leben, 2. Band. Leipzig und Wien: Bibliographisches Institut.

Ratzel, F. (1904[1923]). Über Naturschilderung. München und Berlin: R. Oldenbourg.

Ratzel, F. (1905[1966]). Jugenderinnerungen. München: Kösel.

Ratzel, F. (1905). Glücksinseln und Träume: Gesammelte Aufsätze aus dem Grenzboten. Leipzig: Fr. Wilh. Grunow.

Ratzel, F. (1906). Nationalitäten und Rassen. In H. Helmolt (ed) Kleinere Schriften von Friedrich Ratzel, herausgegeben von Hans Helmolt, 2. Band. München: R. Oldenbourg, 462-487.

Reid, J. (2003). Deleuze's war machine: Nomadism against the state Millennium: Journal of International Studies 32: 57-85.

Ruddick, S. (2017). Rethinking the subject, reimagining worlds. Dialogues in Human Geography 7: 119-139. 
Santini, C. (2017). At the origins of modern geography. The oecumene: am Anthropogeographical pattern. History of European Ideas 43: 560-569.

Sauer, C. O. (1971). The formative years of Ratzel in the United States. Annals of the Association of American Geographers 61: 245-254.

Schultz, H.-D. (2006). Friedrich Ratzel: (k)ein Rassist? Geographische Hochschulmanuskripte 2: $1-46$.

Schultz, H.-D. (2007). "Hätte doch die Erde mehr Raum!" Friedrich Ratzel und sein (politisch)geographisches Weltbild. Mitteilungen der Geographischen Gesellschaft in München 89: 345 .

Schultz, H.-D. (2014). Friedrich Ratzel - Pionier moderner Sozialgeographie? Ein Missverständnis. Kultursoziologie 3: 54-66.

Shaw, I. G. R. (2012). Towards an eventual geography Progress in Human Geography 36: 613-627.

Simon, S. and de Goede, M. (2015). Cybersecurity, bureaucratic vitalism and European emergency. Theory, Culture and Society 32: 79-106.

Smith, W. (1980). Friedrich Ratzel and the origins of Lebensraum. German Studies Review, 3: 5168.

Squire, V. (2015). Reshaping critical geopolitics? The materialist challenge. Review of International Studies 41: 139-159.

Steinmetzler, J. (1956). Die Anthropogeographie Friedrich Ratzels und ihre ideengeschichtlichen Wurzeln. Bonn: Im Selbstverlag des geographischen Instituts.

Sundberg, J. (2014). Decolonizing posthumanist geographies. Cultural Geographies 21: 33-47.

Verne, J. (2017). The neglected "gift" of Ratzel for/from the Indian Ocean: Thoughts on mobilities, materialities and relational spaces. Geographica Helvetica 72: 85-92.

Clausewitz, C. v. (1989[1832]). On war. Princeton: Princeton University Press.

Wanklyn, H. (1961). Friedrich Ratzel: A biographical memoir and bibliography. Cambridge: Cambridge University Press.

Weizman, E. (2007). Hollow land: Israel's architecture of occupation. London: Verso.

Whatmore, S. (2005). Culture-Nature, In P. Cloke, P. Crang and M. Goodwin (Eds) Introducing Human Geographies. Abingdon: Hodder, 8-17. 
Whatmore, S. (2006). Materialist returns: practicing cultural geography in and for a more-thanhuman world Cultural Geographies 13: 600-609.

Woodyer, T. and Geoghegan, H. (2012). (Re)enchanting geography? The nature of being critical and the character of critique in human geography. Progress in Human Geography 37: 19521. 